\title{
Generating Additional Innovation and Research Opportunities during COVID 19 in Device and Technology Development and Associated Clinical, Patient, and Research Activity Benefits through a Clinical Engineering Innovation and Research Team (Tritech Institute)
}

\section{Chris Hopkins*}

Clinical Engineering, Innovation and Research Department ((TriTech Institute), Hywel Dda University Health Board, UK

\begin{abstract}
One positive development from the trials supported during the COVID-19 period has been a muchstrengthened relationship between the Research \& Development (R\&D) and Clinical Engineering departments. Companies seeking to develop new technologies needed to get rapid regulatory approval from the Medicine's \& Healthcare Products Regulatory Agency (MHRA) for CE marking. Achieving such approval required the expert technical input of clinical scientists and engineers within the clinical engineering department, alongside the input of experienced researchers, adept at designing studies and gaining ethical approval. Simply put, we found our local supply chain could not interface with the NHS without Clinical Engineering and R\&D support. Both R\&D and Clinical Engineering considered there to be significant merit in continuing this joint working through the establishment of a joint function that optimised the supply of new, novel, effective, and safe technologies benefitting staff and patients.
\end{abstract}

\section{Keywords}

Clinical Engineering, Medical devices, Technology, Research

\section{Background}

The Research and Development (R\&D) department has over several years been successful in working closely with industry to support research studies leading to the development of new drugs and technologies. It has invested in a dedicated researcher development and grants function, which supports staff from across the University Health Board (UHB) to design research studies, often working with external partners, leading to the development of new technologies that improve health outcomes for patients. The researcher development and grants function also generates an income to cover its costs. The R\&D department was develop- ing a new strategic plan, which sought to develop upon this good record but recognising some of the challenges that were ahead.

One of the most significant challenges was maintaining research activity given the pressures on the system associated with COVID 19, which has been both positive and negative for research activity [1]. Positively, it has led to far more clinicians wishing to be involved in studies that enable their patients to be offered treatments only available through participation in a trial. This has also been supported and encouraged, as innovation and R\&D have become core business and key pillars of the UK Government and Welsh Government response

\footnotetext{
*Corresponding author: Chris Hopkins, Clinical Engineering, Innovation and Research Department (TriTech Institute), Hywel Dda University Health Board, UK

Accepted: March 04, 2021; Published: March 06, 2021

Copyright: (c) 2021 HopkinsC. This is an open-access article distributed under the terms of the Creative Commons Attribution License, which permits unrestricted use, distribution, and reproduction in any medium, provided the original author and source are credited.
}

Hopkins. Int J Healthc Syst Eng 2021, 3:005

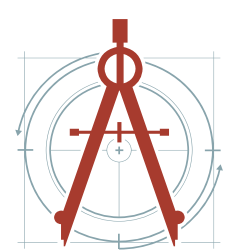

Citation: Hopkins C (2021) Generating Additional Innovation and Research Opportunities during COVID 19 in Device and Technology Development and Associated Clinical, Patient, and Research Activity Benefits through a Clinical Engineering Innovation and Research Team (TriTech Institute). Int J Healthc Syst Eng 3:005 
to the pandemic. Negatively, it has meant that it has not been possible to undertake as many non COVID-19 studies, and while some studies are starting to restart, this is a challenge that we anticipate will remain for some time yet.

As part of developing the new strategic plan, therefore, the R\&D Department is identifying new areas that can help it maintain and develop its level of research activity, while maximising the benefits delivered to patients and citizens. Through supporting local businesses with new technology developments, the R\&D department has also discovered how it can assist the local circular economy by making the conduct of trials within the NHS more efficient.

One positive development from the trials supported during COVID-19 has been a much strengthened relationship between the R\&D and clinical engineering departments. Companies seeking to develop new technologies needed to get rapid regulatory approval from the Medicine's \& Healthcare Products Regulatory Agency (MHRA) for CE marking. Achieving such approval required the expert technical input of clinical scientists within the clinical engineering department, alongside the input of experienced researchers, adept at designing studies and gaining ethical approval. Simply put, we found our local supply chain could not interface with the NHS without Clinical Engineering and R\&D support. Some examples of the work already undertaken are listed below:

- Clinically/scientifically led development of a variant on a continuous positive airway pressure (CPAP) machine with a local engineering company [2].

- Consultancy services across Wales on the development of respiratory equipment.
- Consultancy services across Wales on anaesthetic machine development.

- Working with the University on the production and supply of oxygen saturation monitors.

- Utilising a local engineering company to supply drip stands for COVID Field Hospitals.

- Providing a quality assurance service to develop PPE visors.

\section{Methods}

Both R\&D and Clinical Engineering considered there to be significant merit in continuing this joint working through the establishment of a joint function that:

- Optimised the supply of new, novel, effective, and safe technologies benefitting staff and patients;

- Increased the number and quality of new technology and device trials - underpinned by Value Based Healthcare (VBHC) [3]; and

- Nurtured the local supply chain, for wider economic and related health gain.

\section{SWOT}

The function provides an end-to-end service that walks companies through the regulatory approval process, offering the necessary research and development input, and results in patient benefits and gains to the health board and local economy by making it easier to innovate and develop new technologies. There was an opportunity for both Clinical Engineering and R\&D teams to co-locate within new accommodation to further strengthen working relationships (Table 1 ).

The preferred option saw the creation of a new

Table 1: SWOT.

\begin{tabular}{|l|l|l|}
\hline Option & Advantages & Disadvantages \\
\hline 1 & $\begin{array}{l}\text { Do Nothing. } \\
\text { Teams operate } \\
\text { as currently with } \\
\text { limited joint projects } \\
\text { progressed }\end{array}$ & $\begin{array}{l}\text { Joint working conducted through } \\
\text { COVID-19 unsustainable. }\end{array}$ \\
\hline No & $\begin{array}{l}\text { Some joint projects would be pursued, } \\
\text { as currently is the case but no growth } \\
\text { in technology development. }\end{array}$ & $\begin{array}{l}\text { Missed opportunities with an increasing } \\
\text { number of grants relating to new devices } \\
\text { and technologies. }\end{array}$ \\
\hline
\end{tabular}




\begin{tabular}{|c|c|c|c|}
\hline & & & $\begin{array}{l}\text { With no uplift in new technology and } \\
\text { device research activity, and with an } \\
\text { anticipated decline in drug trials, there is a } \\
\text { potential risk to core HaCRW funding. }\end{array}$ \\
\hline & & & $\begin{array}{l}\text { Insufficient staff to generate income to } \\
\text { cost recover. }\end{array}$ \\
\hline & & & $\begin{array}{l}\text { Less likely to be able to support local } \\
\text { companies with developing new } \\
\text { healthcare technologies that could benefit } \\
\text { the health system, patients, and the } \\
\text { economic prospects of companies. }\end{array}$ \\
\hline & & & $\begin{array}{l}\text { Without co-location of teams, the } \\
\text { opportunities for chance discussions and } \\
\text { the shared use of facilities may limit the } \\
\text { number of innovations and technologies } \\
\text { supported, including related research and } \\
\text { development activity. }\end{array}$ \\
\hline \multirow[t]{3}{*}{2} & $\begin{array}{l}\text { Do minimum. } \\
\text { Co-locate R\&D Core and } \\
\text { Clinical Engineering. No } \\
\text { additional staff. }\end{array}$ & $\begin{array}{l}\text { Low cost. Some investment in } \\
\text { facilities, offset with R\&D core } \\
\text { funding. }\end{array}$ & $\begin{array}{l}\text { The same as option one, minus the } \\
\text { absence of co-location disadvantage. The } \\
\text { most significant disadvantage would be } \\
\text { the ability to identify opportunities but } \\
\text { being unable to capitalise upon them due } \\
\text { to staff capacity and capability limitations. }\end{array}$ \\
\hline & & $\begin{array}{l}\text { Through co-location, easier to identify } \\
\text { and support joint projects and } \\
\text { optimise the use of facilities. }\end{array}$ & \\
\hline & & $\begin{array}{l}\text { Creates a visible 'front door' for } \\
\text { clinical device and new technology } \\
\text { innovation within the organisation. }\end{array}$ & \\
\hline \multirow[t]{3}{*}{3} & $\begin{array}{l}\text { Preferred Option. } \\
\text { Co-locate R\&D Core and } \\
\text { Clinical Engineering. } \\
\text { Small jointly appointed } \\
\text { team established } \\
\text { (further detail below) }\end{array}$ & $\begin{array}{l}\text { Equivalent co-location opportunities } \\
\text { secured. }\end{array}$ & $\begin{array}{l}\text { There is a risk that the investment in the } \\
\text { core team is not recovered in full, with the } \\
\text { consulting, grant and licensing income all } \\
\text { subject to market forces. }\end{array}$ \\
\hline & & $\begin{array}{l}\text { The creation of a dedicated clinical } \\
\text { innovation engineering and research } \\
\text { team allows the capacity to target } \\
\text { the pipeline of new technology grant } \\
\text { schemes, and have a dedicated team } \\
\text { that can support local businesses on } \\
\text { a consultancy basis or through gain } \\
\text { share agreements. }\end{array}$ & $\begin{array}{l}\text { It will take time to develop a device and } \\
\text { new technology trial competence within } \\
\text { the organisation. }\end{array}$ \\
\hline & & $\begin{array}{l}\text { Provide a resource to income } \\
\text { generate, recovering the investment } \\
\text { made in the core team. }\end{array}$ & \\
\hline
\end{tabular}




\begin{tabular}{|c|c|c|c|}
\hline & & $\begin{array}{l}\text { Prudent approach, with virtuous } \\
\text { funding cycle that seeks to cover costs } \\
\text { and re-invest in generating addition } \\
\text { clinical engineering. }\end{array}$ & \\
\hline & & $\begin{array}{l}\text { Taps into the interested of several } \\
\text { clinical teams that are keen to } \\
\text { advance device and technology trials. }\end{array}$ & \\
\hline & & $\begin{array}{l}\text { Potential to mitigate risk by a 'test and } \\
\text { grow approach'. }\end{array}$ & \\
\hline & & $\begin{array}{l}\text { Opportunity to offer something } \\
\text { additive to university and commercial } \\
\text { partners, with mutual benefits } \\
\text { secured. }\end{array}$ & \\
\hline \multirow[t]{4}{*}{4} & $\begin{array}{l}\text { Alternate. Co-locate } \\
\text { R\&D Core and Clinical } \\
\text { Engineering. Larger joint } \\
\text { team established. }\end{array}$ & $\begin{array}{l}\text { As per preferred option, with the } \\
\text { ability to go further and faster, } \\
\text { with increased 'hands' to work up } \\
\text { proposals and conduct projects. }\end{array}$ & $\begin{array}{l}\text { As per option } 3 \text {, but significant risk } \\
\text { associated with cost recovery. }\end{array}$ \\
\hline & & Clear signal of intent to competitors & $\begin{array}{l}\text { There will not be limitless demand for new } \\
\text { device and technology trials. }\end{array}$ \\
\hline & & & $\begin{array}{l}\text { Danger of surplus capacity, if consultancy } \\
\text { and grant capture proves less than } \\
\text { anticipated. }\end{array}$ \\
\hline & & & $\begin{array}{l}\text { Risks associated with overcommitting } \\
\text { (by volume) to technology developments } \\
\text { where the UHB has limited competence. }\end{array}$ \\
\hline
\end{tabular}

team of in-house engineers, scientists, and researchers with a common goal of translating innovative medical technologies into patient benefits. The team spans Clinical Engineering and R\&D providing a multi-disciplinary, cross-sector team combining capabilities in engineering, technology and innovation with strong links to HEls. The preferred option saw the creation of:

- A single point of access for local manufacturers to the university health board (UHB), supporting the development of health technologies that result in health gains, while contributing to regional wealth.

- A capability to compete with other new device and technology research centres to secure prestigious grants and enable an efficient response to external companies looking to CE mark their products in advance of commercialisation.

- An internal consultancy service able to identify areas where the UHB could optimise it's practices through embracing new technologies, including a credible team able to work with clini- cal staff to develop concepts and translate these into innovative medical technologies and processes to benefit patients, staff and the wider health economy.

- A team with the skills and technical experience to manage the end-to-end innovation pathway - from identifying needs and solutions, through design and prototyping the concepts, testing and clinical testing as well as IP advice and implementation, working with University partners, pooling knowledge, expertise, and resources.

The Clinical Engineering Research and Innovation (CEIR) function provides an end-to-end service that walks companies through the regulatory approval process, offering the necessary research and development input, and results in patient benefits and gains to the health board and local economy by making it easier to innovate and develop new technologies (Figure 1).

The new co-located team delivers the following benefits: 


\section{CEIR - INTERFACE BETWEEN TEAMS}

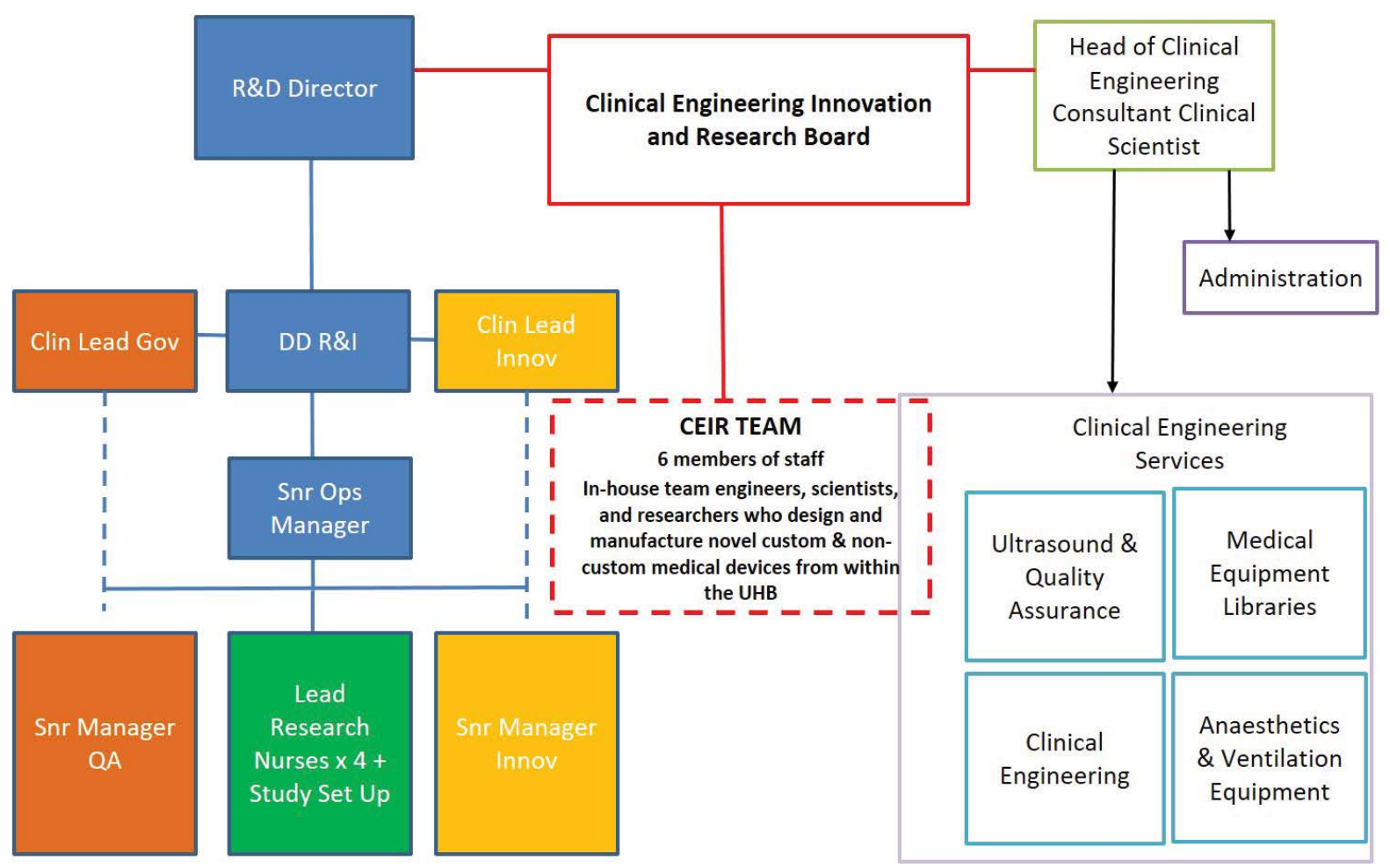

Figure 1: CEIR - Interface between teams.

- Grant capture - securing grants, particularly from prestigious research funders is a time consuming endeavour and is often difficult to carry out alongside busy 'day jobs'. The team maximises the UHB grant yield in areas considered to be of maximum benefit.

- IP Share/Gain - sharpening the UHB's ability secure a 'share' of any proceeds emerging from partnerships with the invention of new technologies and devices whereby it has played an instrumental role in the commercial success of that product through its consulting advice or facilitation of clinical investigations.

- Licences for supporting development - benefitting from preferential access to new technologies at no or low cost, where the UHB has played an instrumental role in their development, potentially avoiding the requirement for such technologies to be procured and the associated cost.

- Research activity. Diversifying the clinical trials that the UHB is able to support, broadening the research portfolio, and protecting recruitment activity that ensures the UHB receives the same or increased Health \& Care Research Wales annual grant.

- Further contributing to the well-known benefits associated with clinical teams and patients being involved in clinical investigations and studies, including improving the standards of clinical practice and contributing to improved clinical outcomes.

\section{Discussion}

There is a risk that the investment in the CEIR team is not recovered in full, with the consulting, grant and licensing income all subject to market forces. It will take time to develop a device and new technology trial competence within the organisation.

From $1^{\text {st }}$ January 2021 the Medicines and Healthcare products Regulatory Agency (MHRA) will take on the responsibilities for the UK medical devices market that are currently undertaken through the EU system [4] and this may have an impact on the team's ability to navigate through the new regulatory frameworks within the UK. 


\section{Conclusion}

The COVID-19 period has resulted in a positive development for the UHB through a much-strengthened relationship between the Research \& Development (R\&D) and Clinical Engineering departments. Expert technical input from clinical scientists and engineers within the clinical engineering department, alongside the input of experienced researchers, adept at designing studies and gaining ethical approval has resulted in the establishment of a joint function that optimises the supply of new, novel, effective, and safe technologies benefitting staff and patients.

\section{References}

1. Harper L, Kalfa N, Beckers GMA, Kaefer M, Nieuwhof-Leppink AJ, et al. (2020) The impact of COVID-19 on research. J Pediatr Urol 16: 715-716.

2. (2020) CPAP device now approved by MHRA. Welsh Government.

3. Muir G (2017) Value based healthcare. BMJ 356: 437.

4. (2020) Guidance: Regulating medical devices. MHRA, UK. 